\title{
INTERVIEW WITH BORIS SKET NOTHING HAS A SENSE IN SPELEOBIOLOGY, WITHOUT A COMPARISON OF CAVE ANIMALS WITH THE 'NORMAL' EPIGEAN ONES
}

\author{
Conducted by IVO LUČIĆ
}

The series of Interviews continues Slovenian, Yugoslav, and Dinaric speleobiologist Boris Sket. His interest in subterranean fauna started in childhood. Professor Sket is one of the pioneering speleobiologists in Slovenia. As a professor at University of Ljubljana, he has been exploring all aspects of cave fauna since 1950s. He also brought speleobiology to University curriculum. He can be considered as a founder of SubBio Lab, a progressive group of speleobiologists from the University of Ljubljana.

\section{PERSONAL AND BEGINNING}

What was attracting you to deal with biology, which is connected to karst? What had influenced you to select it for all your life: childhood experiences, scientific interest, or some important person from the karst world?

Uau, this is a story! Not a majestic story with big names, it is just the modest story of my life. During the World War II we were living in Ljubljana, more or less "imprisoned" in the city, surrounded with a barbed wire fence. Towards the end of the war, still as a schoolboy, I was regularly visiting our museum, where I was particularly attracted (do not ask me why!) by two small bottles with cave crustaceans. These were NIPHARGUS STYGIUS SCHDTE and the shrimp TROGLOCARIS SCHMIDTI DORM. (they are in my possession now). In those time and some years after the war, I was living with my grandparents, since my parents were fighting as partisans. Since my father left his life there, after the war I forced the grandfather to escort me into two or three small caves. I most probably met the niphargus there. I will not tire you with the shrimp story, bound to my later serious caving as a member of the Društvo za raziskovanje jam (simply Caving society) in Ljubljana. This was the beginning. Yes, the childhood experience. And later the resulting scientific interest.

In the secondary school, the professor of biology acquainted me with his son, who was a caver. I started active caving. Later at the university, I met the old professor Hadži, mentioned below. But my direct chief was prof. Janez Matjašič, also interested in speleobiology. He promoted some expeditions to the south of Dinaric karst which was in that times a feat, bound with logistic

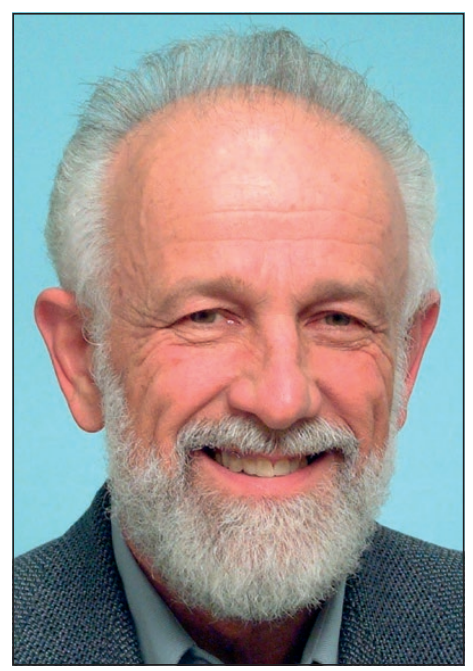

Boris Sket problems and unexpected adventures. The most thrilling were repeated visits to the extremely rich (faunistically) cave Vjetrenica in Hercegovina. The cave was already famous, investigated by local zoologists, by the famous karst researcher Karel Absolon and also by the earlier Slovenian expedition organized by prof. Hadži. Vjetrenica is still hid-

ing some secrets. Fortunately, Vjetrenica was already in those times easier accessible. With a railway station of the narrow-gauge at its entrance!

I would like to tell that caving and speleobiology developed well in Slovenia. The newly born University in Ljubljana, in 1919, invited prof. Jovan Hadži for founding the chair of zoology. And unbelievably, this man from the Pannonian Balkans searched for cavers here, revived the Slovenian caving society and directed it more into science, mainly biology.

Are you, dr. Lučić, still interested and active in exploration of it?

Of course, thank you for asking me. I am grateful to Vjetrenica, which strongly attracted me to nature and karst. However, my research is focused on man's 
relationship to nature, and for that, I don't need to come directly to Vjetrenica. Our previous interviews have been conducted with researchers from geoscientific disciplines in which the subject of research is what materially and symbolically represents the essence of karst. However, biospeleologists are inevitably tied to karst and the underground. How would you define exactly your discipline, its name and subject, as well as attitude towards karst?

Although a general designation of this science is biospeleology, I am feeling being a speleobiologist. So, please, accept this emphasize on biology. Although the discipline started as (bio)speleology and also most individual colleagues start their work as primarily cavers or speleologists, most of them develop into speleobiologists. I do also not accept a separation of this discipline from 'surface-biology' since nothing is understandable, nothing has a sense, without a comparison of cave animals with the 'normal' epigean ones. This my -arbitrary intervention does not exclude the discipline from the speleology, let alone from karstology.

I have also to emphasize that the subject of speleobiology are not only the cave environments and cave biota, we include here all subterranean subject also, biota of interstitial waters in non-consolidated layers. Three important ecological characters are joining both realms - the darkness, paucity of energy (food) resources, and a relative stability of ecological parameters.

The basic aims of the modern speleobiolgy seem to be two: (1) the manysided (physiology, structure, diversity) adaptation to extremely stingy, poor evironment regarding energy (food), and (2) consequences of the

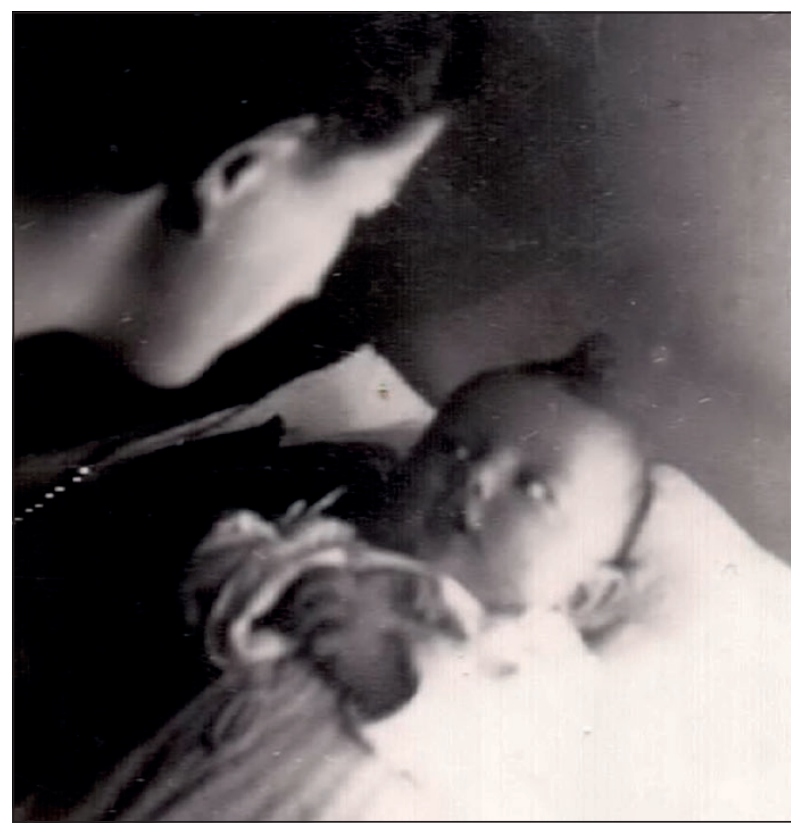

The future speleobiologist Boris Sket with his mother Ada (1936). habitat fragmentation, including the rich and high biodiversity.

Note, please. The great evolutionist Theodosius Dobzhansky said: Nothing in Biology Makes Sense Except in the Light of Evolution, and I would add: Nothing in speleobiology makes sense except in the light of comparison, which is again a support for evolutionary reflections. Therefore the ultimate question of most speleobiological facts is - how or why did it develop, why did it happen. - to be different from the epigean.

Slightly out of this topic is the dull cataloguing of subterranean biodiversity which is also important, but only to some-degree the science. But behind it and potentially after or above it, may again hide much of science. And pleasure, satisfaction.

\section{DEVELOPMENT OF SPELEOBIOLOGY}

How did look like the world of biospeleology at the time you were at the doorstep of those phenomena? How many centers were organized, what was their main interest, which techniques have been used? How much, research conditions have been developed at that time?

I can hardly answer this question. There are just few centers (but there are!), speleobiologists are mainly scattered through the World. The techniques are the same as techniques in biology. Of course additionally, all caving techniques may be used for the access to habitats and biota. But the most special speleobiology technique are probably cave laboratories which allow to breed cave animals and to observe processes in the natural environment.

What was the perception of speleobiology in karstology's circles in time you were young researcher?

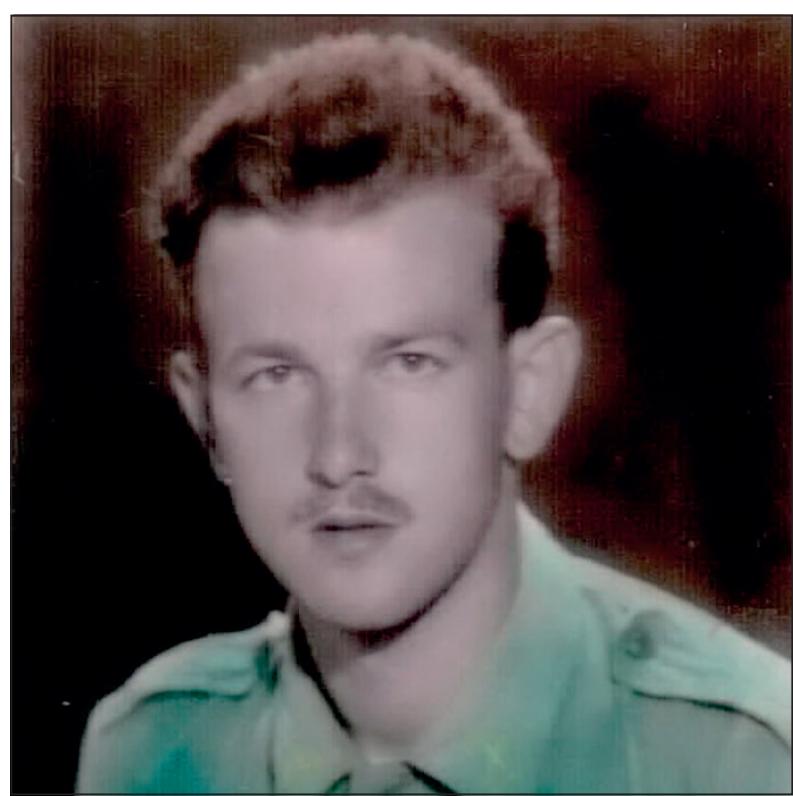

Serving the Army and investigating caves around Valjevo, Serbia (1962). 


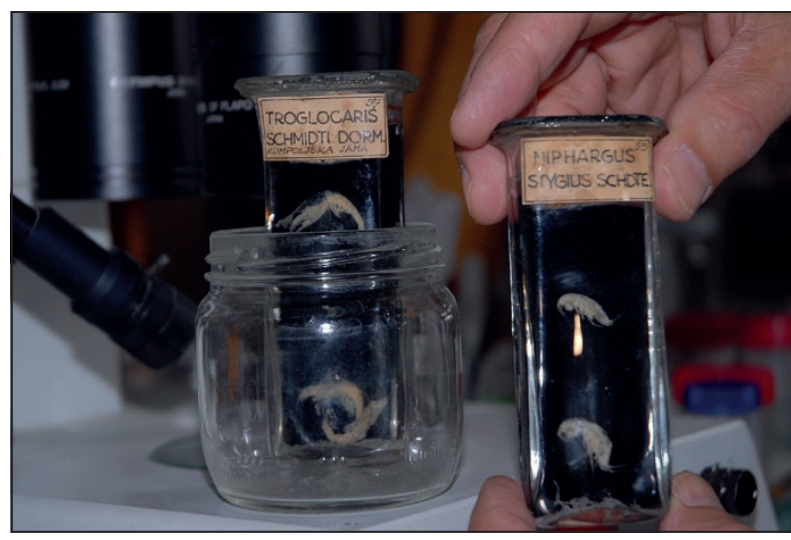

Fatal bottles and the epigean division of his working domain (2008), by Slavko Polak.

How did you feel compared to colleagues of others karstology disciplines, like geography, geology...?

I hope and I feel that speleobiology has been accepted as a part of karstology (and speleology) although it is somehow jutting out. Speleobiologists definitely depend on 'physical' data, therefore the 'physical' speleologists, even amateur cavers, certainly know and feel this and they certainly feel proud and well in our company.

Which were the important phases in the development of subterranean biology, and which were the milestone event?

After the finding of Proteus (which was the 'first' cave animal in the world) and a still accidental finding of the beetle Leptodirus by Luka Čeč, the amateur entomologist Ferdinand Schmidt started actively to search for additional cave animals. This I see as the beginning of biospeleology. Although Racoviță (Racoviță 1907) evidently invented the name biospeology, by the others improved to biospeleology, his Essai sur les problèmes biospèologiques is in fact the birth document of speleobiology (Sket 2006). Let's say that he is not its godfather, Racoviță is just its father.

Speleobiology gradually accepted, included, more and more factual biology. If we accept caving and caving techniques as self-evident ingredient of it ... So the biospeleology-speleobiology started by taxonomy and faunistics, but accepted genetics, nowadays molecular genetics, physiology, biogeography etc, etc.

I see no essential difference between the 'epigean' and cave biology. The cave biologist may be even supplied with his research objects by a caver non-biologist, not even approaching personally the cave. Cave biology without seeing the cave may exist. And his research techniques do not differ from other biology. The defining character is only the subject of the research. A defined organism, defined environment. Essential is the biology. Biology makes it a science.

\section{KARSTOLOGY TODAY}

How much of a general karst science $e$ is needed for your research?

I need all aspects of karst science. Karst meteorology, chemistry and similar to build the ecology. Geography, paleogeography, to explain biogeography. Etc. And simple caving, including climbing and cave diving, to reach the cave animals for any purpose.

Can you describe your approach to biospeleology? Can you resist modesty and try to be objective: what do you see as your best contributions to sciences?

My approach is very general. I am a very curious person. And I will easily resist my modesty since it is only vestigial.

Of course, all I did was done in company of my colleagues.

- My particular pleasure was a comprehensive research of the Postojna-Planina Cave System (PPCS) with ca 100 troglobiotic and many non-troglobiotic inhabitants and with a rich ecological evidence. PPCS seems to be, along with the Hercegovinian Vjetreni$\mathrm{ca}$, the cave with the highest number of troglobionts. Globally! The advantage of PPCS is the fact, that it harbors also a number of non-troglobiotic species, which are nearly absent in Vjetrenica. This allowed some theoretical considerations regarding the ecology and the formation of cave faunas.

- I turned attention to the importance of competition to understand colonization of the underground and

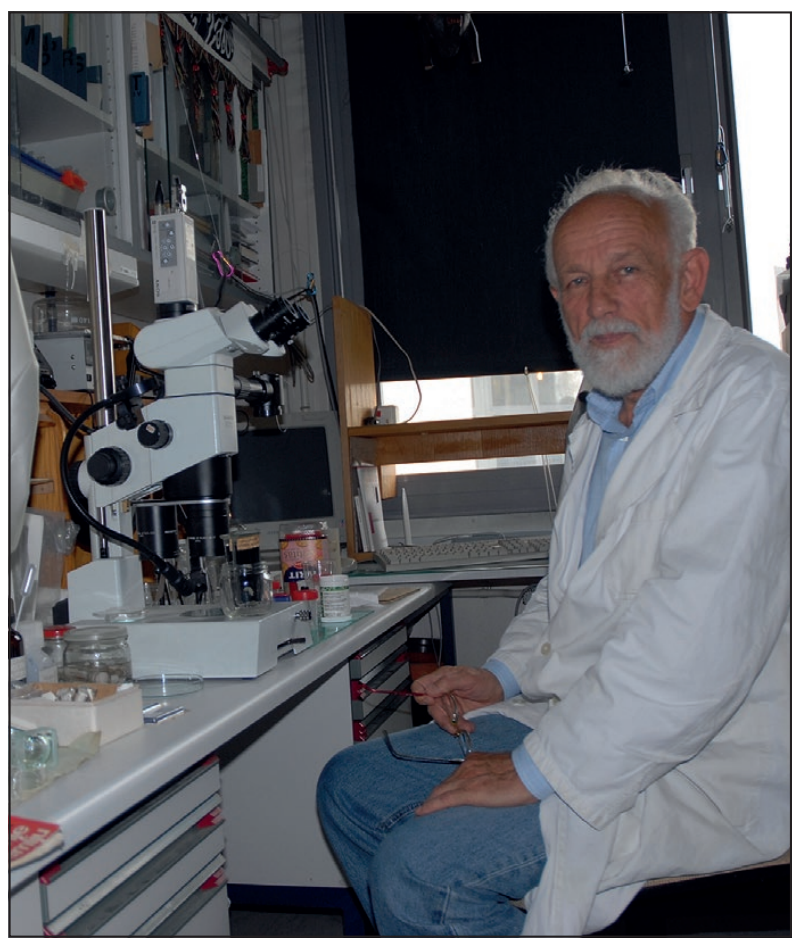

Sket in office, by Slavko Polak. 
to the importance of food input (and organic pollution) for understanding of the fauna composition. In this context also e.g.,Gegenseitige Beeinflussung der Wasserpollution und des Höhlenmilieus.

- I started the investigation of interstitial fauna in Slovenia and we markedly enriched the list of our cave and interstitial fauna. For this reason and for caving, I crisscrossed Slovenia (and much of Yugoslavia) by bicycle. Such were the times...

- I found and described the only cave cnidarian (Velkovrhia enigmatica) and the first troglobiotic sponge (Eunapius subterraneus). I found and described the new family of Isopoda (Atlantasellidae) in Bermu$\mathrm{da}$, and we described another family from Brazil (Brasileirinidae) - and some other interesting creatures.

- I also noticed the biotic nature of the 'cave gold' (Megušar \& Sket 1977) and so initiated the research of the rich bacterial associations on cave walls.

- I did the globally first ecological investigations of anchihaline (or anchialine) caves (an article of this topic even reprinted in the edition Benchmark Papers in Karst Science).

- Well, there is more. E.g biogeographic patterns in Dinaric underground or the "Sket Bottle", the 'marine' ontogeny of the cave tube-worm Marifugia. Definition of the cave hygropetric...

Sorry, you asked me to resist modesty!

What is speleobiology today? What is its most significant interest today? What does speleobiology see as the most crucial target now?

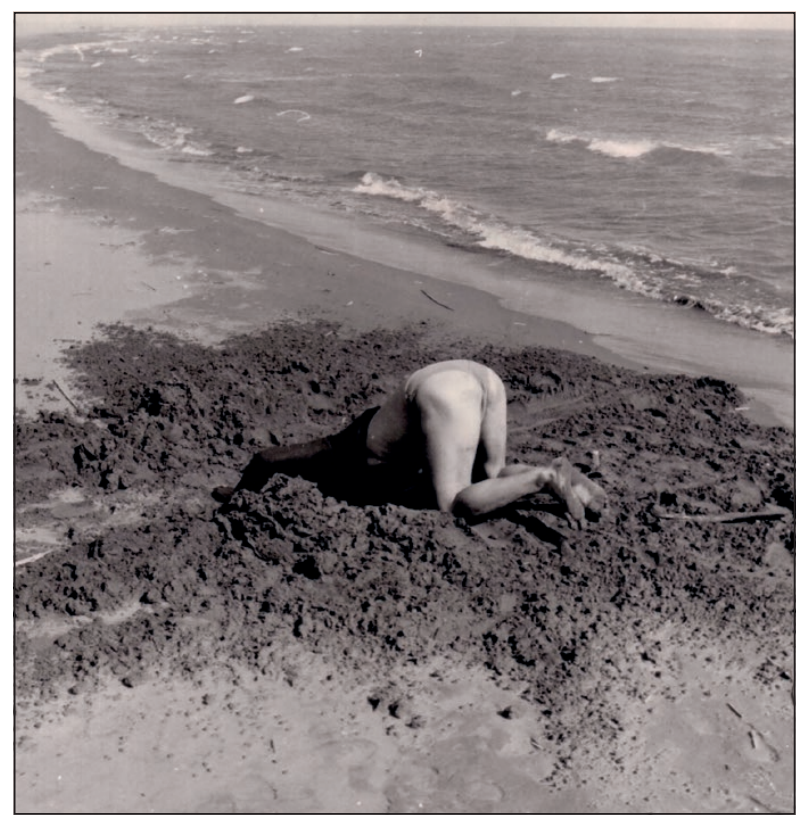

Sampling interstitial fauna at Ulcinj, Montenegro.
Important are mainly two aspects

(1) biodiversity - which depends on molecular genetics,

(2) adaptation - depending on morphology, physiology, genetics. A very sophisticated research direction.

Of course, the ecology, particularly relation of subterranean biota to the input of inorganic and/or organic pollutants is in these times increasingly important.

Which regional centers seem to you most productive and most looking forward in speleobiology?

Difficult to decide. There are in fact no very extensive centers in speleobiology. As already said, researchers are mainly scattered. But there are numerous in France, USA. Also Germany. Not to forget Romania, since the very beginning of speleobiology. And my Slovenia and its neighbouring countries. I cannot name the important researchers, I would certainly be biased, partial and unfair.

The speleobiology has its professional societies, on the national and the world level. What do you say about the idea of establishing a karstology association?

I think that the speleology association in fact already embraces most of the entire karstology, i.e. most karstologists. Serious speleologists do not limit themselves to the 'caves', to the underground. So, we could simply rename the speleological association to the karstological association. The membership would remain approximately the same.

Here is just a small 'problem', the research of interstitial waters would fall out, would be an exterior observer! You know, it would be difficult today to investigate the cave fauna, ignoring the interstitial one. So intricate are the things, so matted is the living world.

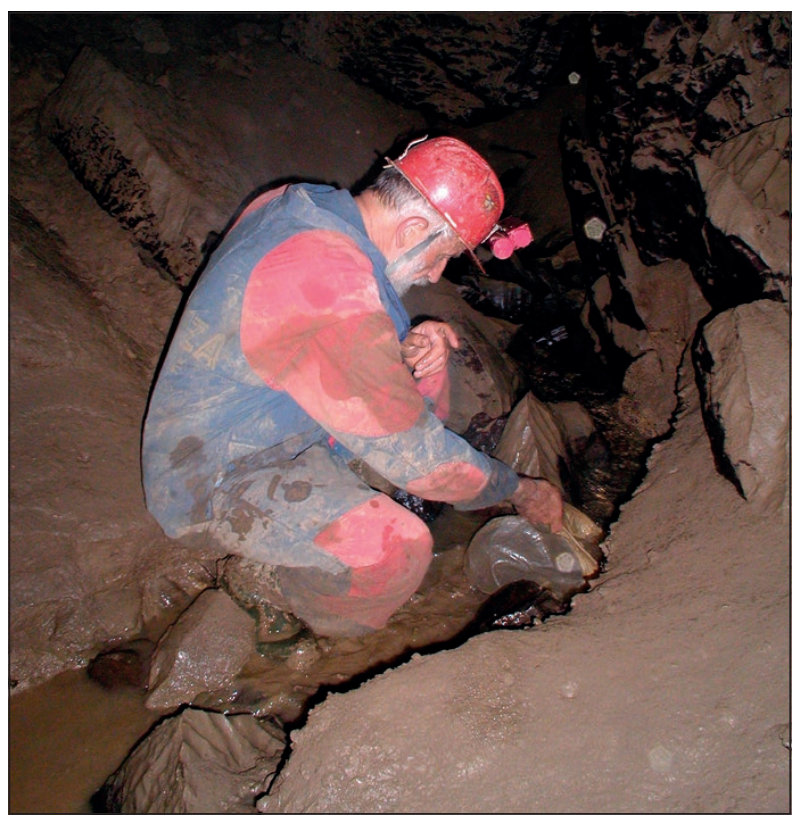

Sampling the cave fauna in Gašpinova Jama (2003), by Miran Nagode. 


\section{DINARIC KARST}

Please, would you sketch the main features, values, research, environmental problems, and visions of the national speleobiology you belong to?

The cave fauna of the Dinaric karst seems to be the richest in the World. Or close to that. The richest 'per square mile', I mean, not per country. So this is an area particularly suitable for any research. Also in this sense - in comparison.

Dinaric karst is recognized as the birthplace of speleobiology and karstology at all. How do you see the role of Dinaric karst in speleobiology today? Which research centers in Dinarides have abilities to answer on contemporary problems of speleobiology? Which are the types of information originated from Dinaric karst nowadays?

Dinaric karst is still the source of numerous findings, it is still attracting curiosity.

Of course, 'karst' stems from the Dinaric toponym Kras (Italian Carso, German Karst). If in historic times Slovenia were not closer at hand than e.g., Philippines, we would now probably speak about bohol and bohology. A mere chance. Of course the investigative indigenous people contributed. E.g. the modest 'cave lamplighter' Luka Čeč who discovered the beautiful inner parts of Postojnska jama, brought later to the daylight the first cave beetle, Leptodirus. The only possibility - in his pocket.

Particularly in last decades the speleology highly developed in Slovenia, with its two million of inhabitants and $20,000 \mathrm{~km}^{2}$ area, there are close to 30 caving

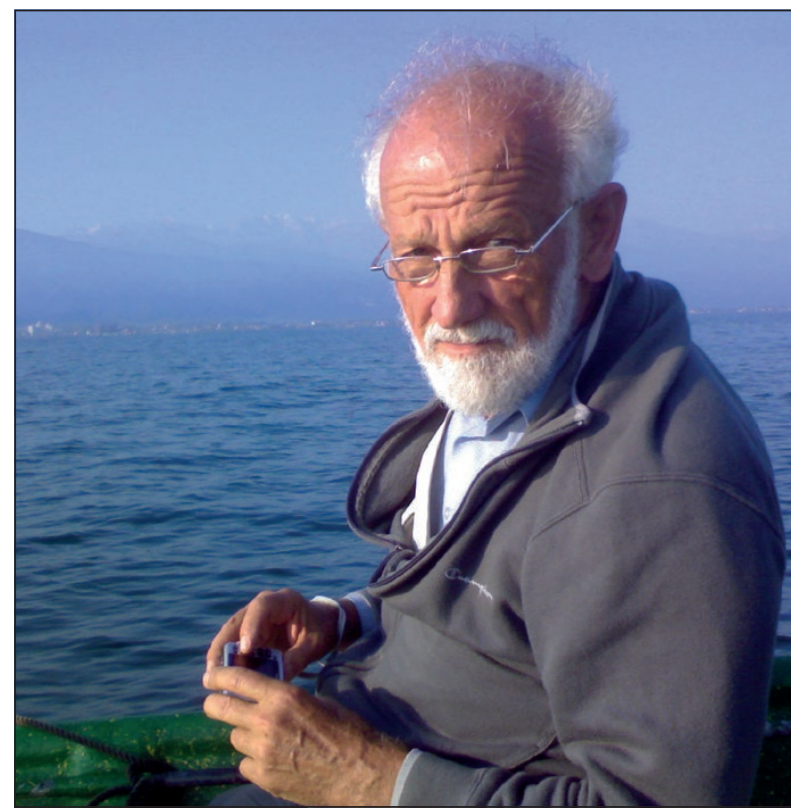

Disappointed. He found no interstitial fauna in the Caspian shore. September / October 2009, by Alireza Mirzajani. clubs or groups which are a rich base for cave explorers and speleologists.

And speleobiology is pretty well developed at the Department of biology at the University of Ljubljana. The research is or was very diverse: biodiversity, phylogeny (navadays by DNA analysis), ecology, biogeography, ethology, something else.

There are research centers also in some other countries of the former Yugoslavia.

In Croatia, a Society for biospeleology exists. Very active. They are most active in biodiversity research and in popularization.

Outside the area, as already mentioned, speleobiologists are most active in France, and in USA. Well, the Romania is also stepping out, since the beginnings, and probably I forgot an important center.

\section{PUBLICATIONS AND POPULARIZATIONS}

How much does karstology, especially speleobiology, take care of popularization, and how much does it tend to go behind its discipline boundaries? How much speleobiology invests in its popularization?

Most active in popularization of their subterranean biodiversity are Croatian speleobiologists. Othervise, we are mainly limited to scientific publications along with some scarce popular leaflets. However, the international speleobiology produces important books of scientific or popular nature. The amphibian, the first found 'cave animal', Proteus anguinus is a much exploited mannequin for these activities. Particularly in Slovenia and in Croatia.

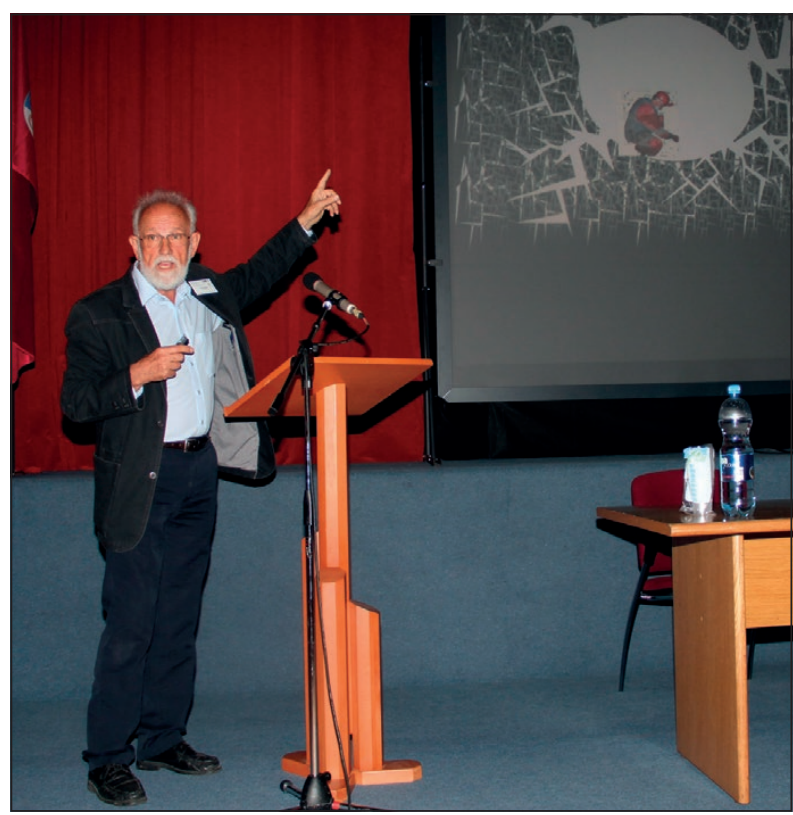

Explaining his ideas in Postojna Conference, by Franjo Drole. 
